\title{
エンドミル加工における切削抵抗予測手法* \\ Prediction Method for Cutting Force in Endmilling Process
}

\section{金子順一** \\ Junichi KANEKO}

Key words cutting force, machining, simulation, prediction, GPGPU

\section{1. は じめに}

近年の数值制御切削加工においては, 複雑形状の創成に 際して工具経路, 機械動作が非常に複雑となるため, CAM ソフトゥエアによって計画された経路を事前検証す るシミュレーション技術が広く用いられている。これらの シミュレーションは, (1)工具経路生成エラーによる削り残 し, 削りすぎの検出, (2)工作機械内部での主軸, 加工対象 物, 把持具, 刃物台間での衝突の検出, といった幾何的な 工具移動領域の評価や, ポスト処理後の工作機械運動の可 視化を対象としており，独立したソフトゥエアシステムと しての商用化や，CAMソフトウエアへの機能統合が広く 実施されている.

一方, 近年の切削加工に上る難削材加工や切削時間短縮 の要求にともない, 従来の幾何的な検証に加えて, 工具切 れ刃による加工対象物除去による切削プロセスの影響を事 前予測する需要が高まっている. 工具に作用する負荷（切 削 3 分力, トルク等) をシミュレーションによって予測 し, 工具経路上での過大な負荷の作用する領域を検出する ことによって，工具に作用する負荷が各工具位置で一定と なるように送り速度を事前に調整し，総加工時間を大幅に 短縮する手法が提案されつつある。

本稿では, これらの工具負荷の事前予測に関して, 必要 とされる計算機モデルの種類や切込深さ推定手法の相違に ついて解説し, 現在筆者らの研究室において取り組んでい る幾何形状処理の高速化技術を紹介する。

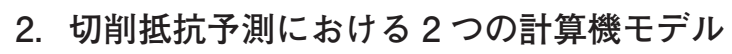

図 1 は, 工具負荷の事前予測において予測対象とされ る切削 3 分力の例を示している. 切削 3 分力では, 工具の 進行方向, および軸方向に対して切削時の工具への負荷の 変動が，工具一回転中の工具軸方向，拈よびそれに直交す る各方向への作用力として表される. 従来, 工具摩耗量等

*原稿受付 平成 29 年 1 月 3 日

*正 会 員 埼玉大学大学院理工学研究科（さいたま市桜区下大久保 255)
の評価においては，工具に作用するトルクは単位時間当た りの切削除去体積にほぼ比例するとして, 工具への負荷を 推定する手法が用いられてきた。一方, 複雑形状加工にお いては，単位時間当たり除去体積が同一の場合でも，除去 の形態 (ダウンカット/アップカット, 側面加工/溝加工) の相違から, 一回転中のトルク変動が大きく変化する場合 があるため，瞬時切削抵抗を用いた評価が必須となる。

上記のような瞬時切削抵抗を予測するシステムは, 大別 して図 2 に示すような異なる二つの計算機モデルから構 成される。一つは工具切れ刃の各部に作用する切削抵抗の 大きさを定量的に予測するプロセスモデルであり，もう一 つは任意の工具経路上での工具位置・工具回転角におい て, 工具切れ刃と加工対象物表面との干渉領域（エンゲー ジメント）を推定する幾何モデルとなる.

\section{3. 切削抵抗予測におけるプロセスモデル}

各種の切削条件 (切削速度, 切込みの梁さ, 工具切れ刃 形状, クーラント, 加工対象物材質等）から切削抵抗を予 測するプロセスモデルについては, 過去から多数の研究が 行われている，これらは大別すると，切屑の流出方向を求 めるエネルギー解法や有限要素法といった解析的モデル と, 切込み深さから工具切狆刃各部に作用する力を関係式 によって推定する経験的モデルとに分類される.

解析的モデルは, 基本的な物性が既知である新素材や, 工具切れ刃形状が切削抵抗に与える影響といった切削プロ セスそのものの検証に有効である半面，予測時の計算負荷 が大きい. 近年では, AdvantEdge（ThirdWave 社）を はじめとする商用の 3 次元解析システムは, 切削工具開発 や複合材料や積層材量といった新素材の加工条件検証に使 用される例が多い.

経験的モデルは, 予測時の計算負荷が低く, ほほ工具運 動に対してリアルタイム（工具一回転分で数 msec）での 計算が可能である半面, 事前に切削実験によるモデルパラ メータの同定が必須となる，具体的には，加工に使用する のと同種の切㞦形状を有する工具や被削物を用いた切削 実験を実施し、モデルパラメータを推定する。回転工具で 

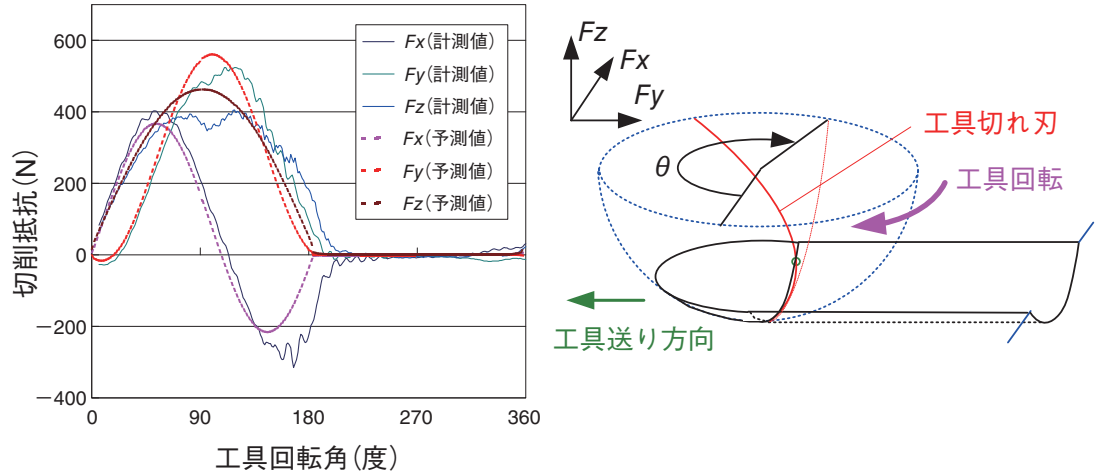

図 1 ボールエンドミル加工に抢ける切削 3 分力の予測例と計測結果例

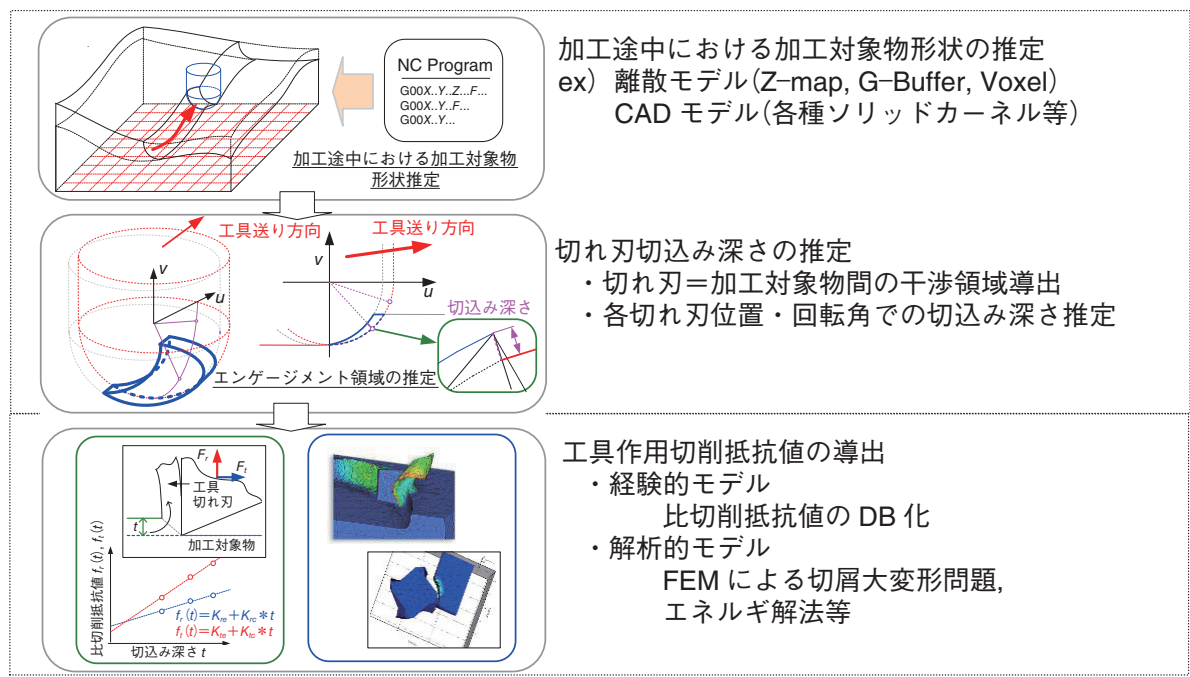

図 2 瞬時切削力予測を実現する計算機モデルの構成

あるエンドミルにおける推定では，工具切れ刃を微小長さ ごとの独立した領域に分割し，それぞれに作用する力を切 込み深さに対する主分力，背分力に分けてパラメータを決 定する必要があり，効果的な推定アルゴリズムの提案が行 われている。近年では，切削実験に代わり，先の FEM で の解析結果を利用して切削負荷を推定する AdvantEdge Production Module（ThirdWave 社）等の新しい試みも見 られる。

\section{4. 切削抵抗予測における幾何モデル}

近年の複雑形状のエンドミル加工の特徴として, 工具切 れ刃が一回転中に加工対象物の表面を除去する，いわゆる エンゲージメント領域の形状が工具位置において大きく変 化することが挙げられる。これまで，スクエアエンドミル を用いた側面加工や溝加工といった一般的な切削加工で は，エンゲージメント領域の幾何的な推定は容易であり， 先述の解析的モデルを適用して工具への負荷を予測する研 究が多く行われている。

ところが，一般的なエンドミルに対して，自由曲面を対
象としたボールエンドミルやブルノーズエンドミルといっ た切削工具では，加工対象物の形状が複雑化する傾向にあ る。特に図 3 に示すような素材からの直彫り加工におい ては, 加工対象物の表面形状は逐次変化する。特に中仕上 げ以降の段階では，前工程で加工面に生じた削り残しの領 域やカスプ形状を除去することが主な目的となることか ら，工具負荷の監視を切削経路全域に対して微小間隔で実 施するためには，素材形状の変化を工具移動に対して切削 抵抗の予測に十分な精度で逐次評価し，エンゲージメント 領域を推定する必要がある。

これまでの研究では, このエンゲージメント領域の導出 に一般的な切削シミュレーションの手法を用いることがよ く行われてきた。まず，加工途中の加工対象物の形状をシ ミュレーションの手法で逐次推定し, 導出された形状の情 報と工具刃先の通過軌跡との干渉を判定してエンゲージメ ント領域を導出する。この種のアプローチによるエンゲー ジメント領域の導出例では, 3DCADのソリッドカーネル を用いて加工対象物の形状変化を再現する手法 ${ }^{1)}, Z$ Z Map モデルを用いて工具軸方向からの加工対象物表面形 


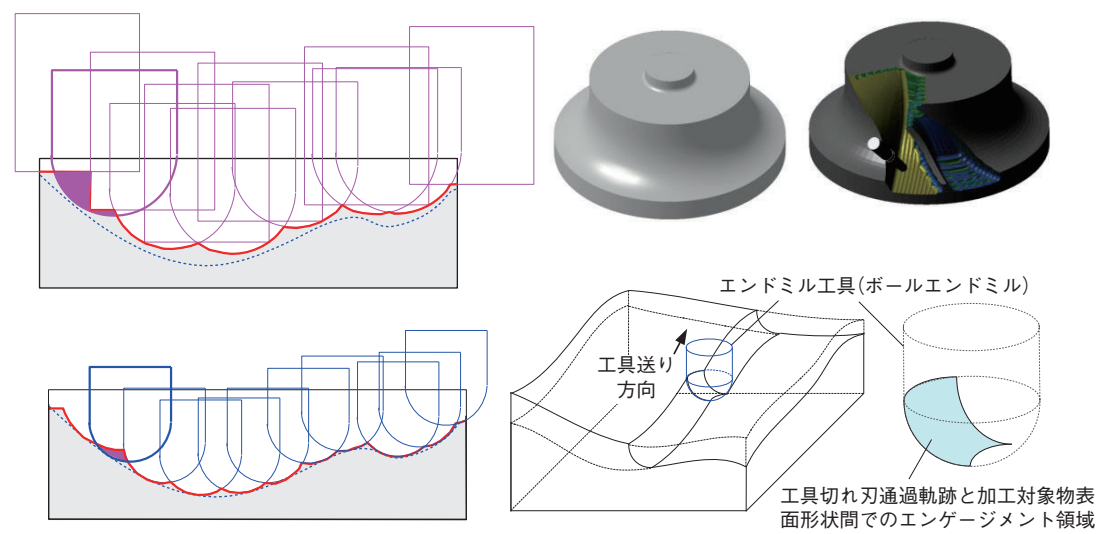

図 3 複雑形状創成加工におけるエンゲージメント領域の変化
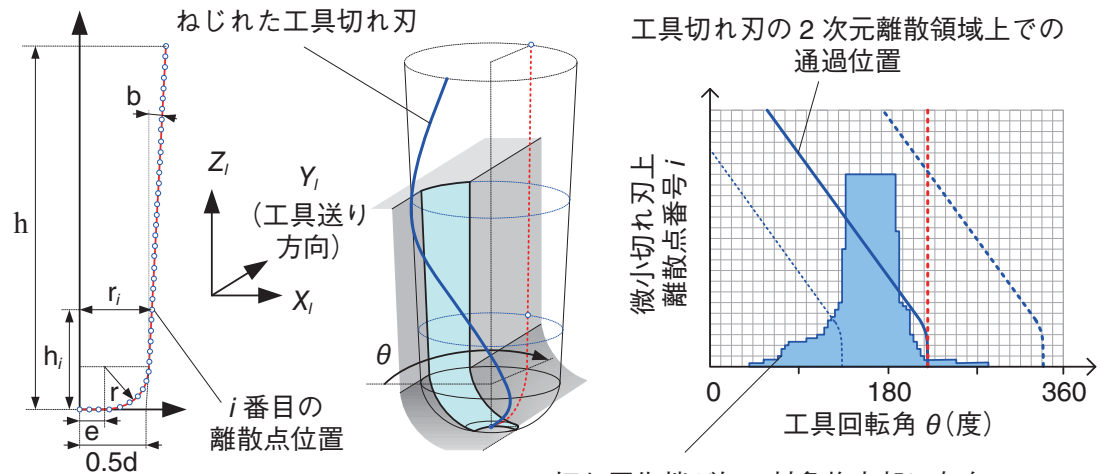

切れ刃先端が加工対象物内部に存在 (=切削)が発生している領域

図 4 工具切れ刃通過軌跡における切込み状態の多数の離散領域による近似的記述

状を推定し，これと工具との干渉を推定する手法2), Voxel 形状表現に再帰的分割を導入する手法 ${ }^{3}$ や距離属性 を追加して高精度な推定を可能とする手法)等が提案され ている.

\section{5. エンゲージメント領域の分散処理による 推定と内外判定}

従来, 研究において提案されてきたエンゲージメント領 域の推定手法では, いったん加工対象物の形状を推定し, これと工具切れ刃との干渉を判定していた。 そのため, プ レス金型や航空機部品といった比較的大規模な加工対象物 に対して，工具移動にともなう形状情報の短時間での更新 と高精度な形状記述を両立させることは難しく, 過大な切 削抵抗の作用を実際の切削時間に合わせて微小工具移動量 ごとに実時間で検出することは，いまだ害用されていない 状態にある

これに対して筆者らの研究室では，切削抵抗予測時の工 ンゲージメント領域の導出に特化した専用の幾何形状処理 アルゴリズムを提案している，提案手法では，加工対象物 の加工途中の形状を明示的に変更/記述せず，加工対象物 の初期形状と，工具の通過軌跡の情報から，エンゲージメ ント領域の各箇所が，加工開始時から工具切れ刃が通過す
る瞬間までの間に除去される可能性があったかどうかの推 定を繰り返し行い，エンゲージメント領域の形状を推定し ている.

図 4 にその概要を示す.工具のある瞬間の一周分の通 過領域を，微小切れ刃とその回転軌跡の集合として 2 次元 離散領域として表し, この各領域上に設定された離散点と 加工途中の加工対象物との内外判定を実施する。十分に小 さい間隔を用いて領域を設定することにより，切削抵抗予 測に十分な分解能で工具切れ刃がその位置で切削を行って いるかどうかの推定が可能となる。

このとき, 工具運動 $n$ ステップ目の加工対象物 $\left(\mathrm{MWV}_{n}\right)$ が, 加工開始時の初期領域（IWV）と，それま での工具の通過軌跡（工具掃引領域：TSV）の積領域に よって図 5 のように表されると仮定する。これを利用し， 提案手法では各離散点が加工途中の加工対象物に対して切 り込んでいるかどうかの判定を，これらの領域に対する内 外判定結果の積によって推定する. 工具掃引領域は，一般 に工具の形状とその通過軌跡によって幾何的に定義できる ため,これを用いて工具の中心軸がその運動ステップ中に 対象となる離散点と該当箇所に打ける工具半径よりも近い 領域を通過するかどうかによって内外判定を実施すること ができる。 


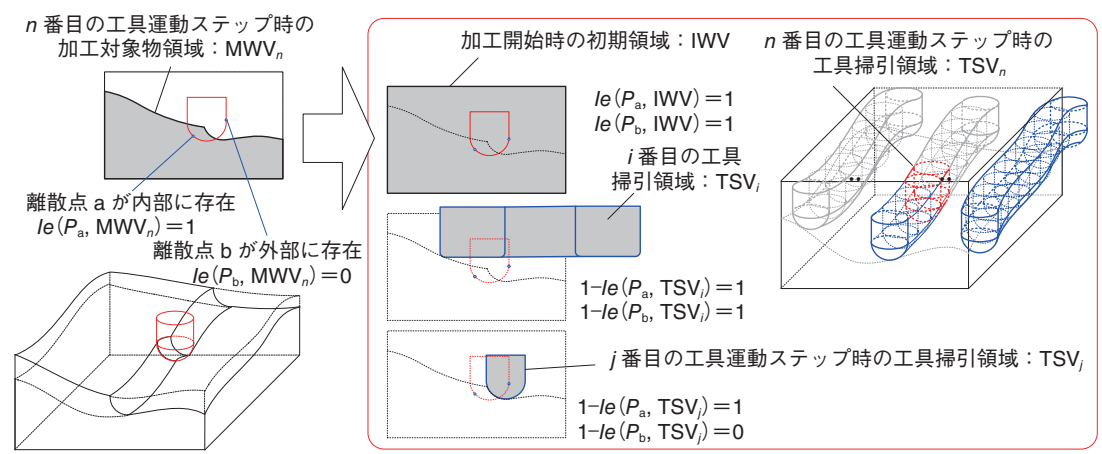

図 5 加工途中の任意段階の加工対象物に対する内外判定の分離

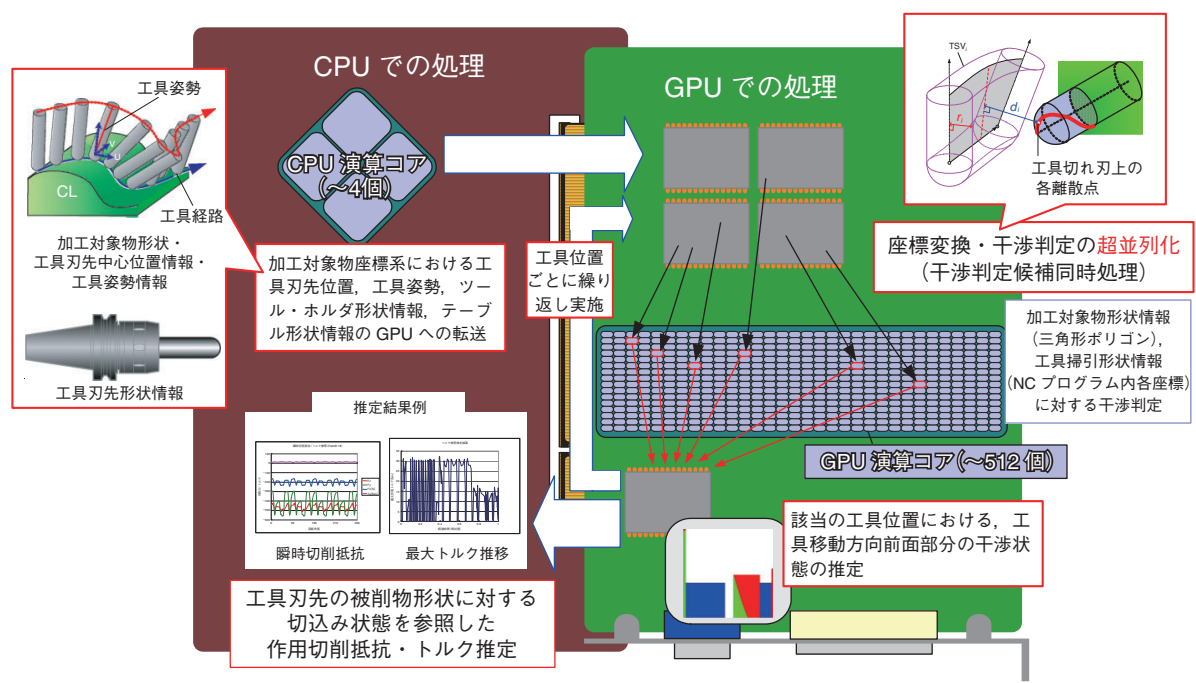

図 6 超並列演算デバイス（GPU）を用いた内外判定処理の並列化

上記のエンゲージメント領域の推定手法においては, 多 数の離散点ごとにこれまで通過したすべての工具通過軌跡 との間で高速な内外判定処理を実現することが計算時間短 縮の必要条件となる。その手段として，本研究ではグラフ イックスハードウエア（GPU）を用いた大規模並列計算 技術を導入し，処理の高速化を実現している。

GPU は，並列動作する計算コアを単一チップ内に数百 個有し，これらを同時並列に動作させることで, 比較的小 規模な計算を高速かつ並列に実施することのできる計算デ バイスである。提案手法では，この計算コアの一つ一つ に, エンゲージメント領域を構成する各離散点を割り当 て, (1)加工開始時の加工対象物の初期形状, (2)各工具掃引 形状との内外判定，の二つの処理を並列して実施するシス テムを開発した。図 6 はその構成を示す。CPU 側で計算 に必要となる各種情報 (工具形状, 工具経路, 加工対象物 初期形状）を準備された GPU は, 内部で各コアにエンゲ ージメント上の離散点を割り当てられ, 順次内外判定を実 施する。対象となる工具位置までの工具掃引領域に対する 判定が終了した時点で, 各領域の結果は統合されて 2 次元 離散領域上の色情報として出力され，これを基に CPU 側 でプロセスモデルを用いた切削抵抗予測が実施される.

\section{6. 同時多軸制御加工に対する適用例}

開発システムをインペラ形状の直彫り加工工程の評価に 適用した例を図 7 に示す。ブルノーズエンドミルを用い た同時 4 軸制御荒加工（a）と，テーパーボールエンドミ ルを用いた同時 5 軸制御中仕上げ加工（b）におけるエン ゲージメント領域の状態が，それぞれ色情報の分布で表現 されており, 斜線部の領域において工具切れ刃による除去 が発生していると考えられる。後者では, 前工程でのカス プを工具が乗り越える瞬間やポケット内面に工具が差し掛 かった際に大きな切削 3 分力の変動が発生しており, この 種の現象の事前予測と工具破損防止を目的とした送り速度 の調整においては，微小な間隔で多数の工具刃先位置での 予測を実施する必要があると考えられた。 今回使用した事 例では，62500 点の離散点によって表現されたエンゲージ メント領域に対して, 工具位置 1 力所当たり平均 150 msec 以内の時間でそれぞれの離散点における切削の有無 を判定し，切削抵抗を予測することが可能となった ${ }^{5)}$.

\section{7. 今後の展 望}

複雑形状創成における切削抵抗の事前予測とその活用は 
各離散点に対する内外判定の可視化結果

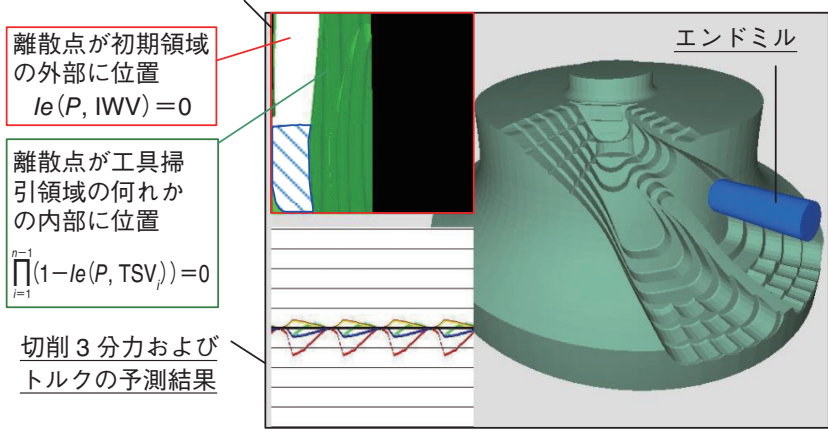

(a) ブルノーズエンドミルによる同時 4 軸制御荒加工の予測例

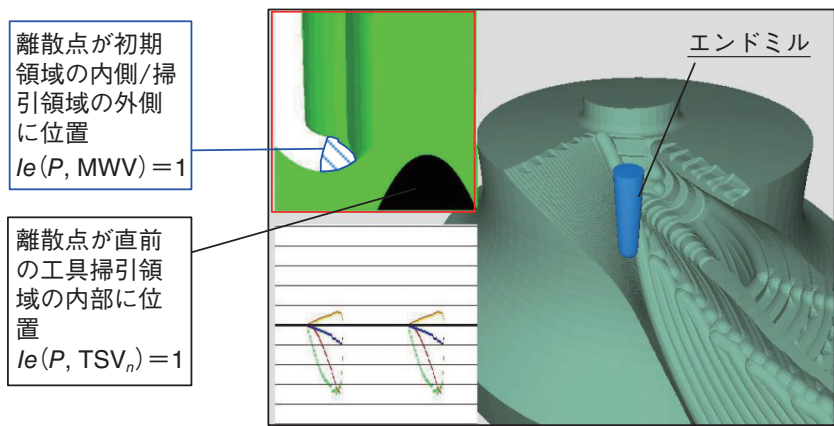

(b) テーパーボールエンドミルによる同時 5 軸制御仕上加工の予測例

図 7 インペラ形状切削時の同時多軸制御加工に扔ける予測例

いまだ発展途上であり，今後は過大切削力の検出や送り速 度変更による加工時間最適化といった CAM ソフトウエア のポスト処理段階だけではなく，切削抵抗の作用を抑制す る工具経路の生成・最適化といった新しい機能の実用化が 期待される，従来，加工対象物の完成形状と工具切れ刃形 状のみを参照し，幾何的な側面のみを考慮していた工具経 路の計画に際し, 各工具位置での切削抵抗作用が参照可能 となることは非常に重要であり, 工具・把持具の剛性や工
作機械の各軸方向への静剛性/動剛性, 各軸の精度/加速度 の相違, 加工対象物の被削性といった従来 CAM オペレー 夕の経験に依存した部分の定量的な評価と加工条件の最適 化が可能になると期待できる。これらの機能を開発するこ とにより，今後いっそう，個々の工作機械が有する性能を 最大限に引き出す工程計画が可能になるのではないかと期 待される。

\section{参 考 文 献}

1）例えば, 岩部洋育, 清水啓輔, 佐々木三宣: 三次元 CAD を活 用したボールエンドミルによる切削機構の解析（傾斜面切削に 扔ける切削面積と評価值による切削特性), 日本機械学会論文集 (C 編)，72,1（2006）247.

2）例えば, 西川隆敏, 菊田敬一, 門藤至宏, 筒元隆博, 金子順 一：エンドミル加工の誤差補償 System（第 1 報）一動たわみモ デルによるボールエンドミル加工の誤差予測と NC データ修正 一，精密工学会誌，78,11（2012）975.

3）例えば, 中本圭一, 河野智之, 小山智, 坂口龍彦, 白瀬敬一 : ボクセルモデルを用いたヴァーチャルマシニングシミュレータ の開発，精密工学会誌，74, 12 (2008） 1308 .

4) S. Alan, E. Huseyin, N.P. Ronald and F.F. Sarah : High accuracy $\mathrm{NC}$ milling simulation using composite adaptively sampled distance fields, J. of Computer-Aided Design, 44 (2012) 522.

5) J. Kaneko and K. Horio: Fast Cutter Workpiece Engagement Estimation Method for Prediction of Instantaneous Cutting Force in Continuous Multi-Axis Controlled Machining, Int. J. of Automation Technology, 7, 4 (2013) 391.

|

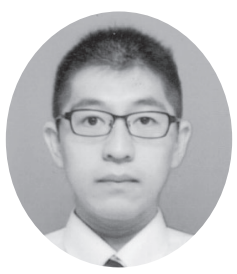
金子順一

2004 年大阪大学大学院修了. 博士 (工学). 研 究内容: 数值制御加工, エンドミル加工, CAM，工具姿勢計画，干渉回避，切削抵抗予 測, 切削シミュレーション, 幾何形状処理, 大 規模並列計算 